\title{
LITERATURA E CINEMA: O FLUXO DE CONSCIÊNCIA EM ESTORVO
}

\author{
Indaiana Aparecida de Almeida ${ }^{1}$
}

\begin{abstract}
Resumo
A presente pesquisa tem por objetivo analisar a obra literária Estorvo, de Chico Buarque, em comparação com a adaptação cinematográfica homônima Estorvo, do diretor Ruy Guerra. Trata-se de uma investigação sobre o fluxo de consciência do narrador-protagonista na obra literária e em sua versão cinematográfica. A análise partiu das referências sobre o fluxo de consciência, relacionando sua abordagem nas obras com um apanhado histórico do autor Chico Buarque e do cineasta Ruy Guerra. Tal proposta teve como objetivo estabelecer um comparativo entre o personagem e seus pensamentos e a maneira como cada uma das obras, livro e filme, representaram essa consciência. Para o presente artigo, foi analisado somente o primeiro capítulo da obra literária.
\end{abstract}

Palavras-chave: Literatura, adaptação, fluxo de consciência, narrador.

\begin{abstract}
The objective of this research is to analyze the literary work Estorvo, written by Chico Buarque, comparing it with the homonymous cinematographic adaptation Estorvo, directed by Ruy Guerra. We research the narrator's position - the protagonist's stream of consciousness in the literary work and in its cinematographic adaptation. The analysis is based on references about the stream of consciousness, by connecting it to the works with a historical study about Chico Buarque and Ruy Guerra. The purpose was to compare how film and literature represent the relationship between the characters and their thoughts. In this article only the first chapter of the book was analyzed.
\end{abstract}

Keywords: Literature, adaptation, stream of consciousness, narrator.

\section{Introdução}

Este artigo apresenta a análise da obra literária Estorvo, de Chico Buarque, em comparação com a adaptação cinematográfica homônima Estorvo, de Ruy Guerra. Não foi analisada a obra toda, mas somente um dos 11 capítulos. No estudo, foi comparado como é retratado, na obra literária e na transposição fílmica, o fluxo de consciência do narradorprotagonista que, tanto na obra literária como no filme não recebeu um nome.

Estorvo é uma narrativa breve, porém densa, complexa, confusa, pois apresenta a história de um personagem e suas alucinações, tentando fugir de alguém, ou, até mesmo, de si. Esse personagem é um homem cuja família é rica, mas não trabalha, e vive perambulando pelas ruas e pelo sítio da família. A narrativa perpassa por meio da visão e consciência do personagem, fazendo com que a ação dos fatos não seja linear, pois há momentos em que ele

\footnotetext{
${ }^{1}$ Licenciada em Letras (Pontifícia Universidade Católica do Paraná), especialista em Literatura Brasileira e História Nacional (Universidade Tecnológica Federal do Paraná).
} 
lembra de sua infância, em outros de quando ele fora casado, apresentando, assim, vários flashbacks ${ }^{2}$.

O objetivo desta pesquisa é responder às seguintes questões: como é representada a técnica do fluxo de consciência do narrador-protagonista na adaptação cinematográfica? Quais os recursos utilizados nessa transposição para que essa técnica se assemelhe ou se diferencie do romance?

\section{Estorvo, de Chico Buarque}

Os anos 80, no Brasil, foram marcados pelo fim da Ditadura Militar. As pressões por eleições resultaram no movimento "Diretas-Já", em 1984, que tinha como objetivo a redemocratização do país. Em 1985, Tancredo Neves, eleito presidente do Brasil de forma indireta, morreu e não chegou a assumir a presidência; em consequência disso, José Sarney, o então vice-presidente, assumiu o cargo. Também em 1985, foi aprovada a eleição direta para presidente, e a ditadura teve seu fim. Ainda nos anos 80, ocorreram fatos como a fundação do Partido dos Trabalhadores (PT) e a Constituição Federal Brasileira (1988). Os anos 90, no Brasil, também foram marcados por acontecimentos como o impeachment de Fernando Collor, o congelamento dos salários, o alto índice de inflação, os movimentos estudantis, o início do Plano Real, a desvalorização do real.

Foi nesse mesmo período, entre os anos 70 e 90, que ocorreram fatos importantes na vida e carreira de Chico Buarque, que nasceu no Rio de Janeiro, em 1944, começou a compor suas músicas em meados da década de 50, entrou para a faculdade de Arquitetura na USP em 1963 (que não concluiu), e escreveu sua primeira peça, Roda Viva, em 1967. A seguir, constam alguns fatos que ocorreram na vida e carreira de Chico Buarque e que foram marcantes: em 1968, ele participa da "Passeata dos Cem Mil Contra o Regime Militar"; em 1969, exila-se na Itália e, segundo Perez (2011), o autor sofre o seu estorvo: “a angústia e a solidão de viver longe dos amigos, longe de sua própria terra. Vivenciou a sensação de desterritorialização tão presente em seus textos através de seus personagens ficcionais como marcas de uma experiência de vida"; em 1970, retorna ao Brasil e compõe a música Apesar de

\footnotetext{
${ }^{2}$ Segundo Robert Stam, a sequência não linear em um texto "gera anacronias", ou seja, "flashbacks, ou memória repentina do passado" e prolepses, que são "flashforwards, ou premonições" (STAM, 2006, p. 37).
} 
você, que é "uma resposta crítica ao regime ditatorial no qual o país ainda estava imerso"3, a canção foi um sucesso, mas foi censurada.

Em 1973, Chico escreveu sua segunda peça, em companhia com o amigo e diretor Ruy Guerra, chamada Calabar. Em 1974, escreveu a "novela pecuária" intitulada Fazenda Modelo, na qual "os bois e outros animais compõem uma alegoria do Brasil da censura, da ditadura, das maravilhas e mazelas do milagre econômico"4. Em 1979, publicou seu primeiro livro infanto-juvenil, Chapeuzinho Amarelo, que apresenta uma releitura do clássico Chapeuzinho Vermelho, mas que trata de uma forma lúdica a questão do medo. Em 1991, publicou seu primeiro romance, Estorvo, com o qual ganhou o prêmio Jabuti; em 1995, publicou Benjamin; em 2003, Budapeste, e em 2009, Leite Derramado. Os três primeiros foram adaptados para o cinema. Além das peças Roda Viva e Calabar, Buarque também escreveu Gota D’Água, em 1975; Ópera do Malandro, em 1978; e O Grande Circo Místico, em 1983.

Estorvo é dividido em 11 capítulos $^{5}$ e narrado em primeira pessoa. Apresenta-se como uma narrativa não linear, ou seja, não há uma ordem consecutiva dos fatos, pois o personagem, em vários momentos, retorna à sua infância (flashback) e imagina possíveis acontecimentos futuros (flashforward). Exemplificando essa "fragmentação", fatos que ocorreram no primeiro capítulo são retomados somente no capítulo cinco. E há falta de linearidade também dentro dos capítulos, pois o personagem apresenta divagações, devaneios e lembranças.

Antes do primeiro capítulo, o romance apresenta uma espécie de "prefácio-epígrafe", com alguns significados e sinônimos da palavra estorvo. Segundo Perez (2011), "trata-se, portanto, da questão da linguagem, da palavra, do desejo de comunicação do escritor":

estorvo, estorvar, exturbare, distúrbio, perturbação, torvação, turva, torvelinho, turbulência, turbilhão, trovão, trouble, trápola, atropelo, tropel, torpor, estupor, estropiar, estrupício, estrovenga, estorvo (BUARQUE, 2004, p. 5).

O protagonista de Estorvo advém de uma família rica, e não trabalha, é um sujeito ocioso, que se envolve em um universo violento e marginal. Ele é:

\footnotetext{
${ }^{3}$ CHICO Buarque. Disponível em: <http://www.chicobuarque.com.br/vida/dir_top_70.htm\#1>. Acesso em: 15 fev. 2013.

${ }^{4}$ CHICO Buarque. Disponível em: <http://www.chicobuarque.com.br/construcao/lit_fazenda.htm>. Acesso em: 07 fev. 2013.

${ }^{5}$ Para esta pesquisa, foi utilizada a $2^{\underline{a}}$ edição, $3^{\text {a }}$ reimpressão do ano de 2004 , publicada pela editora Companhia das Letras.
} 
um herói às avessas, pervertido, cuja errância sem rumo nos remete ao sujeito melancólico do barroco em diálogo com o homem em desassossego do mundo contemporâneo. E, também, do eu-pessoano do início do século XX.

A narrativa do andarilho segue mediante uma tessitura tênue, fragmentada, sem linearidade, através de um relato oscilante entre realismo e delírio, como se o personagem-narrador vivesse em uma "espécie de onirismo desperto" (PEREZ, 2011).

O primeiro capítulo começa com um sujeito que toca a campainha e o narradorpersonagem se vê em um conflito diante do outro em sua porta. Ele vai até a porta, vê o indivíduo, mas não abre. Ele descreve a pessoa e fica muito incomodado com sua presença, acredita que, até mesmo, esteja sendo perseguido: "O terno e a gravata também me incomodam." [...] "Agora me parece claro que ele está me vendo o tempo todo" (BUARQUE, 2004, p. 7-8).

Essa sensação de perseguição, perturbação e de insanidade que acomete o personagem é a "marca do olhar do protagonista, um narrador-anônimo, cuja visão se amplia a partir do objeto - “olho mágico"” (PEREZ, 2011). Esse episódio da campainha, do “olho mágico”, é o primeiro da obra. Em seguida, sucedem-se outros acontecimentos, como a visita até a casa de sua irmã, a cena da rodoviária, a chegada ao sítio, a ligação para sua mãe, encontro com a exmulher, assassinato no prédio, o banho no apartamento da ex-mulher, o roubo das joias da irmã, o trailer e os rapazes, a maconha, a loja que sua ex-mulher trabalha, o delegado, e, por fim, o personagem protagonista é esfaqueado.

A obra apresenta uma crise identitária do personagem e "pontua o estilhaçamento dos ideais e a dificuldade da relação do eu com o mundo" (REBELLO, 2007, p. 177). E esse mundo no qual estamos inseridos representa a era dos avanços tecnológicos, do consumismo frenético, da desigualdade social, da cibernética, do sensacionalismo, das informações em massa, da internet, das terapias psicológicas, e isso tudo reflete no indivíduo. O narradorpersonagem de Estorvo é um sujeito que sofre com todos esses elementos, mas que não são explicitados na obra, porém pode-se perceber uma crise existencial do protagonista, que é consequência desse mundo capitalista e conturbado; segundo Perez, ele age por impulsos e está sempre voltado para si próprio, e isso também representa o caráter individualista e materialista do mundo contemporâneo (PEREZ, 2011).

\section{Estorvo, de Ruy Guerra}

Os anos 2000 foram marcados pela comemoração dos 500 anos do Brasil, o fim do 
mandato de Fernando Henrique Cardoso, a transição do governo tucano para o petista, pois Lula venceu a eleição para presidência em 2002, sendo reeleito em 2006; em 2010, o Brasil elegeu sua primeira presidente mulher, Dilma Rousseff. O início do século XXI foi um período turbulento, em que alguns acontecimentos foram marcantes, como o "apagão elétrico" que ocorreu em 2001, em alguns estados brasileiros, e foi também quando começaram os escândalos políticos, bem como as CPIs (Comissão Parlamentar de Inquérito), entre outros fatos.

No ano 2000, o filme Estorvo foi lançado, sob direção de Ruy Guerra, amigo de Chico. A película apresenta a mesma narrativa do livro, mas por se tratar de outra linguagem, há elementos que diferem no modo como são representados. Os problemas vivenciados pelo personagem, tanto no romance quanto no filme, são processos em contextos diferentes, sofrendo um distanciamento no tempo, mas mesmo com esses contextos históricos e políticos sendo diferentes e terem mudado em 10 anos, o narrador-protagonista apresenta os mesmos conflitos e perturbações.

Ruy Guerra nasceu em Moçambique, em 1931, mas radicou-se no Brasil, em 1958. Foi montador, assistente de direção, fotógrafo e ator ${ }^{6}$. Em 1961, dirigiu seu primeiro longametragem, Os Cafajestes; em 1964, lançou Os Fuzis, um filme brasileiro e argentino, que recebeu o prêmio Urso de Prata no Festival em Berlim; em 1969, lançou o filme Sweet Hunters, produzido no Panamá, e recebeu Medalha de Ouro no Festival de Veneza. Em 1970, lançou Os Deuses e Os Mortos, e em 1978 a comédia A Queda. Em 1986, lançou o filme Ópera dos Malandros, baseado na Ópera dos Três Vinténs, de Bertolt Brecht, e em 1989 o filme Kuarup, baseado na obra de Antônio Callado.

\begin{abstract}
A busca de linguagem é uma constante em meus filmes e tenho uma formação bastante voltada para isso. Algo fundamental para mim é encontrar estruturas que rompem com os conceitos padrões, basicamente da dramaturgia hegemônica norteamericana, que acredito serem redutores da realidade e não servirem para a nossa cultura (MININE, 2003). ${ }^{7}$
\end{abstract}

Esse "rompimento" com a hegemonia norte-americana pode ser verificado em Estorvo, pois Guerra procurou retratar a vida miserável de um indivíduo em busca da

\footnotetext{
${ }^{6}$ Ruy Guerra ganhou vários prêmios e dirigiu outros filmes que não são citados neste trabalho.

${ }^{7}$ Entrevista realizada pelo Periódico Eletrônico A Nova Democracia: MININE, Rosa. Ruy Guerra - a autenticidade do cinema brasileiro, A Nova Democracia, n. 7, março/2003. Disponível em: <http://www.anovademocracia.com.br/no-7/1223-ruy-guerra-a-autenticidade-do-cinema-brasileiro>. Acesso em: 08 fev. 2013.
} 
sobrevivência, apresentando uma linguagem completamente diferente. A película expressa a realidade da "falta de horizonte e perspectiva profissional", segundo o diretor. O cineasta acredita que os jovens estão passando por um período sem ideais, aspirações, angustiados, vivendo o seu estorvo neste mundo.

Ainda nesta entrevista para o periódico eletrônico A Nova Democracia, Guerra aborda a questão do cinema nacional. Sob esse aspecto, o Brasil regrediu. Na década de 60, o país tinha mais de 5 mil salas de cinema, e hoje existem apenas um sétimo disso. Ele afirma que "mesmo naquela época, e hoje com muito mais intensidade, existia um certo bloqueio para os filmes nacionais, porque as casas de distribuição já estavam vinculadas à produção

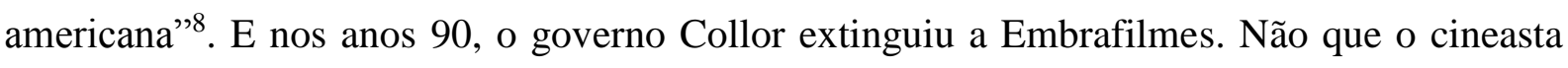
considerasse uma excelente produtora para os filmes nacionais, mas, segundo ele, acreditava que a Empresa Brasileira de Filmes não deveria ter fechado as portas, mas sim ter sido substituída. O cineasta acredita que "todo esse estrangulamento da produção no Brasil afetou o povo quanto ao hábito de ver filmes brasileiros" e que "não é com um único filme que se recupera isso, mas, sim, com uma série deles".

De acordo com Bernardet (apud BALLERINI, 2012, p. 29), no período entre os anos 60 e 70, "a produção cinematográfica brasileira ainda sofria com a questão econômica", pois "até aquele momento não havia uma legislação clara que garantisse uma cota de exibição para o produto nacional, e sim uma lei que beneficiava apenas as distribuidoras estrangeiras". Segundo Glauber Rocha, alguns fatores propiciavam o subdesenvolvimento econômico do cinema brasileiro, entre esses fatores

\footnotetext{
estão a falência dos financiadores e dos grandes estúdios nacionais e a não transformação de relatórios federais em leis de proteção à indústria nacional. Como soluções, Glauber propôs: a limitação da importação de filmes estrangeiros [...]; taxas mais amenas para a produção nacional; uma melhor distribuição dos lucros advindos das produções [...] (ROCHA apud BALLERINI, 2012, p. 30).
}

Com relação ao filme Estorvo, em outra entrevista para a Revista Agulha, Ruy Guerra é questionado por que o filme "incomoda":

Incomoda porque é profundamente existencialista, porque critica a práxis brutal da sobrevivência humana, porque reflete nitidamente o mal-estar real da sociedade prática. Como estágio de cultura, o filme não é monolítico, ao contrário, conota a inabalável recusa em omitir as decisivas questões suscitadas pelo discurso pós-

\footnotetext{
${ }^{8}$ Idem.
} 
moderno. O que propomos lá no fundo é uma discussão mais clara sobre a utilidade e validade do cinema como arte, e não só como entretenimento vulgar. ${ }^{9}$

Chico Buarque e Ruy Guerra são amigos desde a década de 70, quando escreveram a peça Calabar, que foi proibida pela censura pois tratava de questões sobre lealdade e patriotismo. Juntos também escreveram as canções para Calabar, chamadas Tatuagem e Fado Tropical, e trabalharam na adaptação de Ópera do Malandro, baseada no livro de Bertolt Brecht $^{10}$. A adaptação de Guerra captou a essência do romance, essa individualidade humana, a subjetividade e a luta pela sobrevivência em meio à sociedade. A arte, segundo o diretor, é um "meio que dispomos para desvelar aquilo que cotidianamente nos tornam ocultos em nós próprios [...] nada melhor do que a serena meditação filosófica para instaurar uma nova dimensão crítica em que vivemos" $"$. Após esse apanhado sobre Chico Buarque e Ruy Guerra, no próximo tópico constará o referencial teórico sobre o fluxo de consciência, elemento que será analisado nas duas obras, livro e filme.

\section{O fluxo de consciência}

A origem dessa técnica literária ainda é discutida e definida de várias maneiras. Em virtude disso, não são encontradas muitas obras em língua portuguesa sobre o tema, encontram-se mais teorias em inglês e na área da Psicologia, pois o fluxo de consciência era um termo utilizado somente nesse ramo, mas na busca de "representar o livre movimento interno da consciência, chegou-se à expressão fluxo de consciência, conforme Humphrey (1975, p. 1), apropriando-se do conceito [...] para aplicá-lo à crítica literária” (SILVA, 2009, p. 25).

O termo stream of consciousness foi criado por William James, em $1890^{12}$, para "indicar um sistema para a apresentação de aspectos psicológicos do personagem na ficção" (HUMPHREY, 1976, p. 1). Segundo Mograbi, a

[...] crítica literária apropriou-se da frase stream of consciousness ou ainda stream of thought ou stream of subjective life, criada pelo psicólogo William James. O primeiro uso do termo pelo americano ocorreu em sua publicação The principles of

\footnotetext{
${ }^{9}$ CÂMARA, Ruy. O estorvo segundo Ruy Guerra. Revista Agulha, n. 6, Fortaleza/São Paulo, ago./set. 2000. Disponível em: < http://www.revista.agulha.nom.br/agulha6guerra.htm>. Acesso em: 08 fev. 2013.

10 Parceria com Chico Buarque é antig[a]. Folha, 27 abr. 2000. Disponível em: <http://www1.folha.uol.com.br/fsp/ilustrad/fq2704200017.htm>. Acesso em: 08 fev. 2013.

${ }^{11}$ Idem nota 10.

${ }^{12}$ A primeira apresentação desse termo está em The Principles of Psychology. Nova York, Henry Holt, 1890.
} 
psychology (1890) e visava exprimir a continuidade dos processos mentais expressos na narrativa. Na verdade, James queria indicar que a consciência não é fragmentada em pedaços sucessivos, pois não há junturas, mas sim um fluxo contínuo (MOGRABI, 2006).

Essa técnica, na literatura, foi desenvolvida para os romancistas "disporem à inspeção dos leitores o que seria impossível na vida real, isto é, engendrariam vias que revelassem as imaginações das vidas íntimas das personagens ficcionais" (MOGRABI, 2006) e também para "exprimir a continuidade dos processos mentais" (CARVALHO, 2012, p. 57) do personagem. James criou esse termo para mostrar que a consciência não é dividida em pedaços contínuos, mas sim um fluxo contínuo. Segundo Carvalho (2012, p. 57), essa técnica pode ser definida como "a apresentação idealmente exata, não analisada, do que se passa na consciência de um ou mais personagens".

[...] trata-se, na arte literária, de uma técnica - mais precisamente um conjunto de técnicas - que registra uma grande variedade de pensamentos e sentimentos de uma personagem sem apresentar amarras restritivas a qualquer argumento lógico ou sequência narrativa. Esse tipo de escritor tenta, através desse método narrativo, refletir todas as forças internas e externas que influenciam a psicologia de uma personagem em um momento singular (MOGRABI, 2006).

Verifica-se que o fluxo de consciência explora os níveis de consciência que antecedem a fala do personagem, revelando, portanto, seu estado psíquico. Humphrey acredita que o intuito de incorporar a consciência humana na ficção é uma tentativa de analisar a natureza humana $(1976$, p. 6), pois ele considera que essa técnica deve ser estudada no nível em que a Psicologia se mescla à Epistemologia, à Filosofia. Ainda segundo Humphrey, o fluxo de consciência pode ser considerado uma experiência mental e espiritual, tanto "que" quanto “como", ou seja, "o 'que' inclui as categorias de experiências mentais: sensações, lembranças, imaginações, concepções, intuições. O 'como' inclui as simbolizações, os sentimentos e os processos de associação" (HUMPHREY, 1976, p. 7). Portanto, quando um romancista escreve uma obra utilizando o fluxo de consciência ele está ampliando a arte da ficção, descrevendo os estados interiores de seus personagens ${ }^{13}$.

Segundo Silva (2009, p. 25), o conteúdo da consciência consiste no "pensamento, que se desdobra num fluxo, ainda segundo James, saltitando de ideia em ideia, movimento causado pelas percepções dos objetos externos, de onde as ideias se constroem e se originam".

\footnotetext{
${ }^{13}$ Idem.
} 
Mograbi (2006), partindo da concepção de Humphrey, afirma que "o fluxo de consciência por si só - apesar de sua dependência aos procedimentos técnicos - não constitui uma técnica propriamente dita, e sim um método irrigado por técnicas". Essa "irrigação" foi classificada por Robert Humphrey em quatro técnicas para a apresentação do fluxo de consciência, são elas: monólogo interior direto, monólogo interior indireto, descrição onisciente e solilóquio. Carvalho (2012, p. 60-66) apresenta essa classificação, entretanto, com algumas alterações. Ele mantém algumas delas, mas ao invés de monólogo interior indireto, ele utiliza o termo monólogo interior orientado, pois, para ele, "indireto" é menos preciso e sujeito a objeções. Substitui o monólogo interior direto por monólogo interior livre e acrescenta a técnica da impressão sensorial. Para apresentar o significado de cada técnica, serão utilizados os dois autores, Humphrey e Carvalho, de maneira que um complemente o outro.

- Monólogo interior direto (livre): é apresentado com pouca interferência do autor e, geralmente, em primeira pessoa. “[...] apresenta a consciência diretamente ao leitor quase sem interferência do autor; isto é, o autor desaparece completamente ou quase completamente da página com suas guias de "ele disse" e "ele pensou" e com comentários explicativos" (DUJARDIN apud HUMPHREY, 1976, p. 22). Este monólogo é apresentado como se não houvesse nenhum leitor. Com relação ao papel do autor na ficção, Humphrey (1976, p. 25) afirma que "o aparecimento do autor é mais frequente e necessário em monólogos de personagens psicologicamente complexos ou naqueles que descrevem um nível mais profundo de consciência”.

- Monólogo interior indireto (orientado): há a presença constante do autor onisciente ${ }^{14}$, em que ele apresenta um material "não pronunciado, como se viesse diretamente da consciência do personagem e, através de comentários e descrições, conduz o leitor [...]" (HUMPHREY, 1976, p. 27).

- Descrição por autor onisciente: essa técnica consiste na apresentação dos pensamentos do personagem "por meio da descrição do autor onisciente que, ao fazê-lo, usa a sua própria linguagem, e não o estilo peculiar do personagem"

\footnotetext{
${ }^{14} \mathrm{O}$ autor onisciente é aquele que conhece o enredo e os personagens. "O autor penetra na mente dos personagens e nos desvenda os seus pensamentos e sentimentos" (CARVALHO, 2012, p. 6). O autor onisciente pode apenas relatar os pensamentos, fatos, como também tecer comentários sobre eles (CARVALHO, 2012, p. $6)$.
} 
(CARVALHO, 2012, p. 66). Acrescentando, Humphrey afirma que essa técnica também é utilizada para "representar o conteúdo e os processos psíquicos de um personagem no qual um autor onisciente descreve essa psique através de métodos convencionais de narração e descrição" (1976, p. 30).

- Solilóquio: é a técnica "de representar o teor e os processos psíquicos de um personagem diretamente do personagem para o leitor sem a presença do autor, mas com uma plateia tacitamente suposta" (HUMPHREY, 1976, p. 32). Complementando, segundo Carvalho (2012, p. 65), “os pensamentos são enunciados como se o fossem para ser ouvidos".

- Impressão sensorial: essa técnica ocorre de forma passiva, "com registro apenas das expressões verbais correspondentes às impressões psíquicas trazidas pelos sentidos" (BOWLING apud CARVALHO, 2012, p. 65).

Humphrey afirma que "a atividade da consciência deve ter conteúdo", esse conteúdo é fornecido "pelo poder que tem uma coisa de sugerir outra, através de uma associação de qualidades [...]" (1976, p. 38). Existem três fatores, segundo Humphrey, que controlam essa associação: primeiro, a memória, que é sua base; segundo, os sentidos, que a guiam; e terceiro, a imaginação, que determina sua elasticidade. $\mathrm{O}$ autor afirma que toda a ficção do fluxo de consciência depende dos princípios da livre associação, pois essa associação é utilizada pelos escritores para "orientar a direção dos fluxos de seus personagens" (1976, p. 44).

Para finalizar este tópico, há uma citação de Silva que sintetiza o fluxo de consciência:

[...] o propósito de sugerir uma reflexão sobre a literatura de fluxo da consciência na esteira das teorias sobre o romance, compreende-se diacrônica e sincronicamente que se trata de um tipo do fazer literário condizente com o recuo em direção ao eu, mas também de uma maneira da criação literária visando dar forma ao eu sitiado em face da ameaça da catástrofe total e da alienação do mundo produzido (SILVA, 2009, p. 34, grifos do autor).

O próximo tópico apresenta a análise entre obra literária e adaptação cinematográfica, e pretende-se responder a seguinte questão: o personagem protagonista apresenta características de um sujeito isolado, tentando sobreviver ao caos do mundo, sofrendo uma crise existencial? 


\section{Literatura e cinema: análise de Estorvo}

Partindo da contextualização histórica das épocas em que romance e filme foram escritos/produzidos, para a vida do escritor Chico Buarque e do cineasta Ruy Guerra e também sobre fluxo de consciência - cujas teorias fundamentam esta pesquisa - na seção a seguir consta a análise de um capítulo da obra literária em comparação com a adaptação cinematográfica. Para embasar esta análise, serão retomados os conceitos e definições dos autores citados nos tópicos anteriores desta pesquisa.

\section{Capítulo 1 - Olho Mágico}

O romance Estorvo é narrado em primeira pessoa, ou seja, o narrador também se torna um personagem ${ }^{15}$, assumindo a condição de narrador-protagonista. O primeiro capítulo do livro, na adaptação cinematográfica, inicia com a campainha tocando duas vezes e, logo em seguida, a câmera foca (close up) no olho do personagem protagonista, que é interpretado pelo ator Jorge Perugorría, como se esse olhar fosse uma abertura do enredo da película para o espectador. Esse olhar torna-se desfocado, e o protagonista aparenta estar semiacordado, e é quando a câmera focaliza seus pés, e, com essa imagem, é possível observar um quarto um pouco escurecido e distorcido. Ele levanta e vai até a porta, seus passos parecem ser inseguros e frouxos. Os movimentos da câmera são rápidos, trêmulos, muitas vezes, desfocados, ou seja, a câmera representa a subjetividade do narrador, a interiorização do pensamento do narrador protagonista. A película apresenta as falas do protagonista, porém, essas falas não são diretas, quer dizer, elas não saem da boca do personagem enquanto as cenas vão se desenvolvendo. A voz narrativa na adaptação é verificada pela utilização do recurso da vozoff . Segundo Ismail Xavier,

No Brasil, como na França, usa-se em geral a expressão voz-off para toda e qualquer situação em que a fonte emissora da fala não é visível no momento em que ouvimos. Nos Estados Unidos, há uma distinção entre: (1) voz-off, usada especificamente para a voz de uma personagem de ficção que fala sem ser vista mas está presente no espaço da cena; (2) voz-over, usada para aquela situação onde existe uma descontinuidade entre o espaço da imagem e o espaço de onde emana a voz, como acontece, por exemplo, na narração de muitos documentários (voz autoral que fala do estúdio) ou mesmo em filmes de ficção quando a imagem corresponde a um flashback, ou outra situação, onde a voz de quem fala vem de um espaço que não corresponde ao da cena imediatamente vista (1983, p. 459).

\footnotetext{
${ }^{15} \mathrm{O}$ personagem protagonista, tanto no romance quanto na adaptação cinematográfica, não tem nome. Por isso, nesta pesquisa, para citá-lo, serão utilizados os termos "personagem", "personagem protagonista", ou somente "protagonista".
} 
A voz-off é compreendida como a "presença" da voz do personagem na diegese, ou seja, em um espaço “existente”, mas o qual a câmera não mostra. O personagem protagonista em Estorvo está diante da trama por meio das sequências de ações e contextos apresentados anteriormente, porém, além do limite do quadro, ultrapassando a dimensão da imagem. A vozoff é sempre "submetida ao destino do corpo" porque pertence a um personagem que está dentro do espaço da narrativa, quando não ao espaço visível da tela. Em Estorvo (filme), o personagem está na diegese, é visível na tela, mas sua fala não é direta, pois é por meio do recurso da voz-off que ele pronuncia:

\begin{abstract}
Estou zonzo. Deve ser coisa importante. Ouvi a campainha tocar várias vezes. Para mim é muito cedo. Acho que conheço esse rosto. De um tempo distante e confuso. Quando ele pertencia ao sonho. Mas não entendo. É inútil, eu não abro mesmo. Sou capaz de morrer aqui em silêncio. Virar um esqueleto em pé, diante do esqueleto dele. Voltarei para a cama e creio que o sujeito acabará desistindo, convencido de que não há ninguém em casa. Mas agora me parece claro, que ele está me vendo o tempo todo. Desconto a deformação do olho mágico, e sempre há alguém conhecido, mas muito difícil de reconhecer. E alguém que um dia abanou a cabeça, coçou o nariz e saiu do meu campo de visão. Sei que é alguém que há muito tempo esteve comigo, mas que eи não deveria ter visto. E eи não precisava rever. (ESTORVO, 2000, 2'09'"- 4'12'').
\end{abstract}

As falas, nesta cena, representam a consciência do personagem. De acordo com Humphrey, o fluxo de consciência explora os níveis de consciência que antecedem a fala do personagem, revelando, portanto, o estado psíquico dele. No romance, essa consciência pode ser verificada por meio da técnica monólogo interior livre, pois não há interferência do autor, e também, por meio da técnica solilóquio, pois além de não ter interferência do autor, "os pensamentos são enunciados como se o fossem para ser ouvidos”, segundo Carvalho (2012, p. $65)$.

Para a adaptação cinematográfica, os pensamentos do personagem foram "reduzidos" para algumas "falas" em voz-off, devido ser uma linguagem audiovisual, pois muitas das descrições feitas pelo narrador protagonista, no romance, são detalhadas e extensas. O autor Robert Stam (2008, p. 20) afirma que "uma adaptação é automaticamente diferente e original devido à mudança do meio de comunicação". E acrescentando, segundo Pellegrini (2003, p. 16), “a imagem tem, portanto, seus próprios códigos de interação com o espectador, diversos daqueles que a palavra escrita estabelece com o seu leitor". No romance Estorvo, o pensamento do personagem no início pode ser constatado pela escrita: 
Estou zonzo [...]. Deve ser coisa importante, pois ouvi a campainha tocar várias vezes, uma a caminho da porta e pelo menos três dentro do sonho. Vou regulando a vista e começo a achar que conheço aquele rosto de um tempo distante e confuso. [...] O terno e a gravata também me incomodam. [...] E o rosto do sujeito assim frontal e estático embaralha ainda mais o meu julgamento. [...] Recuo cautelosamente, andando no apartamento como dentro d'água. Escorregarei de volta para a cama, e creio que o sujeito acabará desistindo, convencido de que não há ninguém em casa. [...] Não posso dormir com a imagem daquele homem fixo na minha porta. Volto ao olho mágico (BUARQUE, 2004, p. 7-8).

Verifica-se que o personagem, na cena inicial do filme, é afásico, ou seja, não há um discurso direto, mas ele "fala" por meio do recurso da voz-off, pois sua "fala" é "ouvida" na cena, mas como se ela estivesse saindo de seu pensamento, revelando, portanto, seu estado de consciência. O que se pode verificar também é que o olhar do protagonista, no começo da cena, através do olho mágico da porta, mostra "o que e como ele vê o que está do outro lado. O olho que se abre é, ao mesmo tempo, cena visível e agente condutor do modo de ver sugerido pela câmera" (REIS, 2010, p. 66, grifos do autor). Esse "o que" e o "como" o personagem vê é, segundo Humphrey, "uma experiência mental e espiritual, pois 'o que' inclui as categorias de experiências mentais: sensações, lembranças, imaginações, concepções, intuições; e o 'como' inclui as simbolizações, os sentimentos e os processos de associação" (HUMPHREY, 1976, p. 7).

Após esta cena do olho mágico, o protagonista se veste e tenta "fugir" do sujeito que estava a sua porta, pois ele acredita que está sendo perseguido. Ele corre pelas escadas do edifício, até que, finalmente, consegue "escapar" quando entra dentro de um túnel: "Agora escapei. Pensei que ele não ia deixar de me perseguir" (ESTORVO, 2000, 5'25”). Novamente, o que o personagem pensa é transmitido ao espectador por meio de sua voz, no caso, a voz-off.

A cena seguinte é a do porteiro da casa de sua irmã, que diz "Casa 6, tem um cidadão aqui dizendo que é irmão da dona da casa" e imediatamente aparece a imagem do protagonista na câmera de vigilância, como se ele realmente estivesse sendo perseguido, vigiado, e o porteiro diz ao interfone "ok, tá bom". O protagonista entra na casa, sua irmã está sentada no jardim, tomando café. A câmera faz um tipo de "zigue-zague" nesta cena, pois focaliza, de maneira rápida, a irmã, as torradas que ela está passando geleia, as fotos que estão desfocadas, em seguida, as mãos do protagonista, representando uma certa ansiedade ao fazer movimentos repetitivos batendo nos talheres.

A irmã fala da mãe, e o indivíduo lá, sentado, sem dizer uma palavra, de repente, ela 
assina uma folha de cheque em branco, e ele, ao pegar o cheque, toca a mão dela. A irmã diz que precisa sair, pois tem compromisso, e ele a olha, ela diz "não esquece da mamãe". O protagonista, lá, sentado, e a voz-off de seu pensamento diz: “Mamãe é um corpo assim, dissimulado. $O$ que as mãos têm o maior desejo de tocar, não de encontrar a carne, mas para apalpar o próprio movimento" (ESTORVO, 2000, 9’08”). Ele "diz" isso quando vê sua irmã saindo da mesa. Talvez, nessa fala, ele queria expressar, para o espectador, sua libido, suas vontades sexuais. Logo após, o mordomo traz o telefone e ele liga para sua mãe. Sua mãe atende o telefone, e, pela primeira vez no filme, aparece seu discurso direito, ele diz ao telefone "Mamãe (pausa). Não se preocupe mamãe, está tudo bem comigo" (ESTORVO, 2000, 10'10”). Mas, após ele dizer o primeiro “mamãe”, ela desliga o telefone e ele continua falando, mas sozinho. E, assim, o primeiro capítulo do romance, na adaptação fílmica, termina.

No romance, por se tratar de outra linguagem, a verbal escrita, é possível verificar o estado psíquico do personagem, pois ele mesmo revela ao leitor, por meio do uso da técnica solilóquio, ele fala como se houvesse um "ouvinte". Na adaptação fílmica, diferentemente do que é demonstrado no romance, também por se tratar de outra linguagem, a audiovisual, as imagens - além do que é dito pela voz-off do personagem - representam o estado psicológico do personagem. Por exemplo, na cena em que ele senta com sua irmã e toma café com ela, no romance ele diz: "Fico desequilibrado, sozinho naquela mesa oval, olhando o mel, o queijo de cabra, o chá de rosas, pensando na minha mãe" (BUARQUE, 2004, p. 18, grifos do autor), porém, no filme, a imagem mostrada pela câmera é de um sujeito inerte, taciturno, apresentando sim momentos de ansiedade, mas há um momento em que a câmera focaliza nele e não se movimenta, e isso não dá a entender que, neste momento em que ele fica sozinho na mesa, ele esteja "desequilibrado", e sim reflexivo.

Verifica-se neste capítulo inicial do romance, na adaptação cinematográfica, que os movimentos da câmera, a sonoplastia, a tonalidade de sombra, luz das cenas contribuem para a "atmosfera" desse personagem, esses elementos em conjunto representam a confusão mental, a sensação de perseguição que o protagonista sente. Neste primeiro capítulo do filme, percebe-se que as "falas" do personagem não são muitas, mas as poucas que há indicam, de acordo com Humphrey, "a apresentação de aspectos psicológicos do personagem na ficção" (1976, p. 1) por meio do recurso da voz-off. Essa voz revela seu estado mental, o que ele pensa, as suas vontades, sua agitação e os conflitos consigo mesmo. 


\section{Considerações finais}

Adaptar uma obra literária para o cinema implica várias mudanças, devido aos elementos e recursos que compõem essa transposição. Esses elementos, muita vezes, substituem o texto escrito. Pellegrini afirma que "a imagem tem [...] seus próprios códigos de interação com o espectador, diversos daqueles que a palavra escrita estabelece com o seu leitor” (2003, p. 16). Esses códigos podem ser verificados por meio dos recursos utilizados no cinema, tais como: som, áudio, luz, movimento da câmera, cenografia, fotografia, montagem, espaço, técnicas, produção, projeção, etc. A composição do texto narrativo acontece por meio do narrador, do foco narrativo, do enredo, do gênero, das personagens, do espaço, do tempo, do discurso narrativo, do leitor, a forma como o texto está disposto, conjugação dos verbos, descrição dos fatos, etc. No cinema, o leitor acaba por ser espectador, e o narrador, a câmera; o espaço e o tempo são heterogêneos, devido ao movimento e à velocidade conduzida pela câmera.

Além desses elementos que diferem na adaptação cinematográfica e na literatura, a obra original "é escrita num determinado período, influenciada por uma série de códigos de representação e por um momento histórico delimitado, do mesmo modo que a adaptação fílmica dessa obra", segundo Silva (2009). Desse modo, o texto narrativo e a cinematografia podem sofrer um distanciamento no tempo devido às mudanças políticas, sociais, históricas e culturais que o autor da obra e o cineasta vivenciaram. E não apenas por essas mudanças, mas também pelo olhar de cada autor, no caso, escritor e cineasta, para com a obra, pois cada produção insere uma identificação com os valores de seu tempo.

Algumas adaptações oriundas de obras literárias fazem uma releitura do texto, transformando-o de modo que se diferencie do texto original, ao passo que outras adaptações procuram estar próximas do texto de partida. A adaptação do texto narrativo para o cinema provoca modificações, e com relação ao fluxo de consciência no filme Estorvo, em comparação com o romance de Chico Buarque, é possível verificar que o diretor Ruy Guerra utilizou o recurso da voz-off para mostrar o pensamento do personagem protagonista. A vozoff é compreendida como a "presença" da voz do personagem que está dentro do espaço da narrativa fílmica, quando não ao espaço visível da tela. Em Estorvo (filme), o personagem está na diegese, é visível na tela, mas sua fala não é direta, pois é por meio do recurso da voz- 
off que ele pronuncia seus pensamentos, revelando, portanto, seu estado psíquico, seus sentimentos e impressões.

No filme, os movimentos da câmera são rápidos, trêmulos, muitas vezes, desfocados, ou seja, a câmera representou a subjetividade do narrador, a interiorização do pensamento do narrador protagonista. Nos três capítulos analisados do romance, verificou-se que foi por meio das técnicas monólogo interior direto (livre) e solilóquio que o autor apresentou o fluxo de consciência do personagem protagonista, pois a obra não tem um narrador onisciente, que apresenta os personagens e que relata os fatos. O capítulo analisado é revelado sob o "olhar" do personagem protagonista, que assume também papel de narrador, e também, esse personagem "fala" como se houvesse um ouvinte, um interlocutor.

Para a transposição fílmica, foi necessário "reduzir" os pensamentos expressos no romance do personagem protagonista, e também, em alguns momentos, os pensamentos e sentimentos dele diferem da obra original, ou então, não expressam, na película, aquilo que está no romance. Mas alguns elementos diferem não somente por se tratar de outra linguagem, a audiovisual, mas pelo olhar do diretor para determinado trecho do texto. É importante observar que essa "redução" dos pensamentos do personagem protagonista foi feita, pois, em muitos momentos, a imagem traduz aquilo que algumas páginas do romance expressa, e também, essa interação entre obra literária e filme permite ao cineasta uma "interpretação livre do romance [...] e admite-se até que ele pode inverter determinados efeitos, propor uma outra forma de entender certas passagens" (XAVIER, 2003, p. 61). Assim, o diretor tem essa possibilidade de transformar o texto original com recursos e elementos específicos do cinema. (Artigo recebido em 02/08/2013, aprovado em 03/12/2013)

\section{Referências}

BALLERINI, Franthiesco. Cinema brasileiro no século 21: reflexões de cineastas, produtores, distribuidores, exibidores, artistas, críticos e legisladores sobre os rumos da cinematografia nacional. São Paulo: Summus, 2012.

BUARQUE, Chico. Estorvo. São Paulo: Companhia das Letras, 2004.

CÂMARA, Ruy. O estorvo segundo Ruy Guerra. Revista Agulha, n. 6, Fortaleza/São Paulo, ago./set. 2000. Disponível em: <http://www.revista.agulha.nom.br/agulha6guerra.htm>. Acesso em: 08 fev. 2013.

CARVALHO, Alfredo Leme Coelho de. Foco narrativo e fluxo da consciência. São Paulo: Editora Unesp, 2012. 
CHICO Buarque. Disponível em: <http://www.chicobuarque.com.br/construcao/lit_fazenda. htm>. Acesso em: 07 fev. 2013.

ESTORVO. Direção de Ruy Guerra. Brasil: Europa Filmes, 2000. 1 DVD (95 minutos), color.

HISTÓRIA do cinema brasileiro. Disponível em: <http://www.historiadocinemabrasileir o.com.br/ruy-guerra/>. Acesso em: 07 fev. 2013.

HUMPHREY, Robert. O fluxo da consciência. São Paulo: McGraw-Hill do Brasil, 1976.

MININE, Rosa. Ruy Guerra - a autenticidade do cinema brasileiro, A Nova Democracia, n. 7, março/2003. Disponível em: <http://www.anovademocracia.com.br/no-7/1223-ruy-guerra-aautenticidade-do-cinema-brasileiro>. Acesso em: 08 fev. 2013.

MOGRABI, Alexandre Nascimento. A travessia de A barca dos homens de Autran Dourado nas ondas do fluxo de consciência. 137 f. Dissertação (Mestrado em Letras) - Programa de Pós-Graduação, Centro de Ensino Superior de Juiz de Fora. Juiz de Fora, 2006. Disponível em: $\quad<$ http://www.dominiopublico.gov.br/pesquisa/DetalheObraForm.do?select_a ction=\&co_obra=108225>. Acesso em: 07 fev. 2013.

PELLEGRINI, Tânia. Narrativa verbal e narrativa visual: possíveis aproximações. In: Literatura, cinema e televisão. Instituto Itaú Cultural. São Paulo: Editora Senac, 2003.

PEREZ, Tânia Maria de Mattos. Estorvo, de Chico Buarque: uma leitura alegórica. In: CONGRESSO INTERNACIONAL DA ABRALIC, 12., 2011, Curitiba. Anais... Curitiba: Abralic, 2011. Disponível em: <http://www.abralic.org.br/anais/cong2011/AnaisOnline/resum os/TC0623-1.pdf>. Acesso em: 27 jan. 2013.

REBELLO, Ilma da Silva. Identidades em ruínas: uma leitura de Estorvo, de Chico Buarque. Soletras, São Gonçalo, n. 14, p. 177-183, jul./dez. 2007. Disponível em: <http://www.filologia.org.br/soletras/14/15.pdf>. Acesso em: 05 fev. 2013.

REIS, Mírian Sumica Carneiro. Náusea e absurdo: o existencialismo em Estorvo. 81 f. Dissertação (Mestrado em Literatura e Diversidade Cultural) - Universidade Estadual de Feira de Santana, Feira de Santana, 2010. Disponível em: <http://www.dominiopublico.gov. br/pesquisa/DetalheObraForm.do?select_action=\&co_obra=191651>. Acesso em: 13 fev. 2013.

SILVA, Reginaldo Oliveira. Da epopéia burguesa ao fluxo da consciência: a escrita literária em tempos difíceis. Revista Investigações, Recife, v. 22, n. 1, p. 11-35, jan./2009. Disponível em: <http://www.revistainvestigacoes.com.br/Volumes/Vol.22.N1/Investigacoes-Vol22-N1artigo01-Reginaldo-Oliveira-Silva.pdf >. Acesso em: 11 fev. 2013.

SILVA, Marcel Vieira Barreto. Adaptação literária no cinema brasileiro contemporâneo: um painel analítico. Rumores - Revista de Comunicação, Linguagem e Mídias e-ISSN: 1982677X, 2009. São Paulo: Midiato - Grupo de Estudos de Linguagem: Práticas Midiáticas (ECA-USP). Disponível em: <http://www3.usp.br/rumores/visu_art2.asp?cod_atual=10>. Acesso em: 16 mar. 2013.

STAM, Robert. Teoria e prática da adaptação: da fidelidade à intertextualidade. Ilha do Desterro, n. 51, p. 19-53, jul./dez. 2006.

. A literatura através do cinema: realismo, magia e a arte da adaptação. 1. ed. Belo Horizonte: UFMG, 2008. 
STROPIANA, Bruno. Filme estreia em maio ou junho de forma modesta. Folha de S. Paulo, 27 abr. 2000. Entrevista. Disponível em:

<http://www1.folha.uol.com.br/fsp/ilustrad/fq2704200

016.htm>. Acesso em: 08 fev. 2013.

XAVIER, Ismail (Org.). A experiência do cinema. 1. ed. Rio de Janeiro: Graal, 1983.

Do texto ao filme: a trama, a cena e a construção do olhar no cinema. In: Literatura, cinema e televisão. Instituto Itaú Cultural. São Paulo: Editora Senac, 2003. 